\title{
NUP214/ABL1 239 kDa Fusion Protein
}

National Cancer Institute

\section{Source}

National Cancer Institute. NUP214/ABL1239 kDa Fusion Protein. NCI Thesaurus. Code C99193.

A fusion protein ( 239 kDa) encoded by the NUP214/ABL1 fusion gene variant 2 . This protein is comprised of approximately half of the nuclear pore complex protein Nup214, which does not include the nucleoporin GLFG repeat domain, fused to the tyrosineprotein kinase ABL1 protein. 